\title{
Kajian Kelayakan Struktur Bangunan Pasca Kebakaran (Studi Kasus Gedung Pasar Koppas) Kota Padang
}

\author{
Feasibility Study of Post-Fire Building Structure (Case Study \\ Building of Pasar Koppas) Padang City
}

\author{
Elvi Roza Syofyan, Syaiful Amri \& Munafri Alwys
}

Jurusan Teknik Sipil Politeknik Negeri Padang Kampus Limau Manis Padang

Telp.0751-72590 Fax.0751-72576 Email: syofyan_er@yahoo.co.id

\begin{abstract}
In a feasibility study of the structure after the fire ( Case Study Building of Pasar Koppas in Padang ). To obtain preliminary data, building data includes tracking information about the building construction has been done. Then visual inspection includes examination of the structural system of the building and non-structural components, as well as the configuration of the geometry component of the structure. Measurement of the building is intended to determine the configuration of the building. It can also serve as a confirmation of the existing building geometric conditions . Later examination of the damage structure and non- structural components by visual observation. Field trials conducted to obtain the data quality of the material structure of the building, with a non destruxctive and destructive. This activity is a test of the quality of the concrete surface with a hammer concrete test, concrete homogeneity measurement, measurement of the diameter and spacing of reinforcement, concrete cored drill with the core drill tools, observations reinforcement fatigue . While in the laboratory to test the compressive strength of the concrete core and reinforcement tensile test. Taking photographs of the condition of the buildings, structural components and non-structural components for further examination to determine the location of the damage, as well as a guide to determine damage level of the building, in addition to the photographs can serve as documentation. Then the data evaluation and analysis of the structure of the building. From the results of the evaluation and analysis of the feasibility of building structures from Pasar Koppas could be concluded, that the structure and function of the building is still viable . For the convenience of occupancy necessary to repair or retrofitting the proper manner and method by the Government of Padang City.
\end{abstract}

Keywords : structural feasibility , feasibility function , retrofit

\section{PENDAHULUAN}

Pasar Koppas Padang yang berlokasi di Kota Padang, Propinsi Sumatera Barat dibangun tahun 1990. Struktur gedung Pasar Koppas merupakan struktur beton bertulang bertingkat 3 , dengan jumlah lantai 3 termasuk plat dak.

Kebakaran yang terjadi pada hari Senin tanggal 20 Februari 2012 jam 23.45 s/d 06.00 wib, menghangus $34(30,7 \%)$ petak toko pada lantai I pertokoan Pasar Koppas Padang.

Dalam hal ini ada beberapa penelitian pakar tentang pengaruh kebakaran terhadap material beton bertulang, diantaranya;

a. Irma Aswani Ahmad, Nur Anny Suryaningsih Taufieq \& Abdul Hamid Aras (Jurusan Pendidikan Teknik Sipil dan Perencanaan Fakultas Teknik Universitas Negeri Makassar)

Kebakaran pada hakekatnya merupakan reaksi kimia dari combustible material dengan oksigen yang dikenal dengan reaksi pembakaran yang menghasilkan panas. Panas hasil pembakaran ini diteruskan ke massa beton/mortar dengan dua macam mekanisme yakni pertama secara radiasi yaitu pancaran panas diterima oleh permukaan beton sehingga permukaan beton menjadi panas. Pancaran panas akan sangat potensial, jika suhu sumber panas relatif tinggi. Kedua secara konveksi yaitu udara panas yang bertiup/bersinggungan dengan permukaan beton/mortar sehingga beton menjadi panas. Bila tiupan angin semakin kencang, maka 
panas yang dipindahkan dengan cara konveksi semakin banyak.

Tjokrodimuljo (2000) mengatakan bahwa beton pada dasarnya tidak diharapkan mampu menahan panas sampai di atas $250^{\circ} \mathrm{C}$. Akibat panas, beton akan mengalami retak, terkelupas (spalling), dan kehilangan kekuatan. Kehilangan kekuatan terjadi karena perubahan komposisi kimia secara bertahap pada pasta semennya. Selain hal tersebut di atas, panas juga menyebabkan beton berubah warna. Bila beton dipanasi sampai suhu sedikit di atas $300^{\circ} \mathrm{C}$, beton akan berubah warna menjadi merah muda. Jika di atas $600^{\circ} \mathrm{C}$, akan menjadi abu-abu agak hijau dan jika sampai di atas $900^{\circ} \mathrm{C}$ menjadi abuabu. Namun jika sampai di atas $1200^{\circ} \mathrm{C}$ akan berubah menjadi kuning. Dengan demikian, secara kasar dapat diperkirakan berapa suhu tertinggi selama kebakaran berlangsung berdasarkan warna permukaan beton pada pemeriksaan pertama.

Selanjutnya, Ahmad (2001) membahas kelayakan balok beton bertulang pascabakar secara analisis dan eksperimen. Penelitian dilakukan terhadap lima benda uji berbentuk balok beton bertulang. Empat balok dibakar di dalam tungku pada temperatur $200^{\circ} \mathrm{C}$ dan $400^{\circ} \mathrm{C}$ selama \pm 3 jam dan satu balok lain yang tidak dibakar sebagai pembanding. Hubungan tegangan regangan memperlihatkan perubahan kemiringan kurva atau dengan kata lain terjadi penurunan kekakuan sejalan dengan kenaikan temperatur dan diikuti dengan penambahan regangan maksimum.

Adapun hasil penelitian Ahmad dan Taufieq (2006) menyatakan bahwa terjadi penurunan kekuatan pada bangunan beton yang telah dioven. Pada penelitian ini didapatkan kuat tekan pada beton yang tidak dioven sebesar $240,0624 \mathrm{~kg} / \mathrm{cm} 2$. Kekuatan sisa beton yang dioven pada temperatur $200^{\circ} \mathrm{C}$ dan $400^{\circ} \mathrm{C}$ adalah $88,89 \%$ dan $70,15 \%$ dari kekuatan beton normal yang tidak dioven.

Rahmah (2000) menggunakan silinder hasil core case berdiameter $5 \mathrm{~cm}$ dari suatu model balok beton bertulang yang dibakar pada temperatur $200^{\circ} \mathrm{C}, 400^{\circ} \mathrm{C}$, $600^{\circ} \mathrm{C}$, dan $800^{\circ} \mathrm{C}$. Hasil dari penelitian ini adalah terjadi perubahan kuat tekan tiap sentimeter kedalaman core case beton sebesar $0,4 \%$; sedangkan perubahan modulus elastisitas tiap sentimeternya berkisar 1,2\% - 2,2\%.

Menurut Zacoeb dan Anggraini (2005), perubahan temperatur yang cukup tinggi, seperti yang terjadi pada peristiwa kebakaran, akan membawa dampak pada struktur beton. Karena pada proses tersebut akan terjadi suatu siklus pemanasan dan pendinginan yang bergantian, yang akan menyebabkan adanya perubahan fase fisis dan kimiawi secara kompleks. Hal ini akan mempengaruhi kualitas/kekuatan struktur beton tersebut. Pada beton normal mutu tinggi dengan suhu $1200^{\circ} \mathrm{C}$ terjadi penurunan kekuatan tekan sampai tinggal $40 \%$ dari kekuatan awal. Sedangkan pada beton mutu tinggi dengan Silikafume dan Superplasticizer akan mengalami perubahan yang cukup berarti pada suhu tinggi dimana kekuatannya tinggal $35 \%$.

Penelitian yang dilakukan oleh Sirait (2009), menggunakan balok beton bertulang penampang empat persegi ukuran 15 × 25 x 320, terletak pada tumpuan sederhana, bertulangan lemah. Waktu pembakaran mulai dari 30, 60, 90 dan 120 menit dengan balok yang berbeda pada suhu $500^{\circ} \mathrm{C}$ sejak awal hingga akhir pembakaran dan tanpa pembebanan. Pembebanan pada uji lentur menunjukkan penurunan daya pikul sebesar $26 \%$, demikian juga pada uji kuat tekan beton menunjukkan penurunan kuat tekan beton sebesar $65 \%$ dari kekuatan awal.

Hasil penelitian menunjukkan bahwa kuat tekan beton menurun dengan adanya kenaikan temperatur. Beton yang 
telah dipanasi pada temperatur $200^{\circ} \mathrm{C}$, kuat tekan rata-ratanya sisa $85,83 \%$ dari beton normal. Jika dibakar sampai temperatur $400^{\circ} \mathrm{C}$, kuat tekan rataratanya sisa $58,40 \%$. Kekuatan ini akan terus menurun hingga sisa $35,08 \%$ pada temperatur $600^{\circ} \mathrm{C}$.

b. A.A. Gede Sutapa (Dosen Jurusan Teknik Sipil, Fakultas Teknik Universitas Udayana, Denpasar)

Porositas dapat didefinisikan sebagai perbandingan volume pori-pori (volume yang dapat ditempati oleh fluida) terhadap volume total beton. Ruang pori pada beton umumnya terjadi akibat kesalahan dalam pelaksanaan dan pengecoran seperti: factor air-semen yang berpengaruh pada lekatan antara pasta semen dengan agregat, besar kecilnya nilai slump, pemilihan tipe susunan gradasi agregat gabungan, maupun terhadap lamanya pemadatan. Semakin tinggi tingkat kepadatan pada beton maka semakin besar mutu beton itu sendiri, sebaliknya semakin besar porositas beton, maka kekuatan beton akan semakin kecil.

Penelitian terhadap porositas lebih didasarkan dari segi keawetan dan kekuatan beton itu sendiri. Dari segi keawetan, porositas sangat penting diteliti terutama pada bangunan tepi pantai dan bangunan yang bersinggungan dengan tanah. Pada bangunan tepi pantai, beton akan bersinggungan dengan air garam yang mengandung sulfat dan klorida yang dapat meresap ke dalam beton sehingga dapat merusak bahkan menghancurkan beton. Kerusakan beton terjadi ketika kedua zat tersebut menguap sehingga di dalam pori-pori beton timbul kristalkristal sulfat dan klorida yang akan mendesak pori-pori dinding beton. Akibatnya, beton pecah menjadi serpihan-serpihan lepas. Karena proses tersebut berjalan terus menerus dalam kurun waktu lama, kekuatan beton akan berkurang dan terancam hancur. Selain garam air laut, kandungan sulfat
(MgSO4, CaSO4, NaSO4) juga dapat menggerogoti beton. Akibatnya beton akan retak-retak, bahkan menjadi rapuh. MgSO4 bahkan mampu melarutkan beton, sehingga yang tertinggal hanyalah batu-batu kerikil dan pasir tanpa semen (Sudarmadi, 2006).

Beton pasca terbakar umumnya memiliki persentase porositas yang lebih besar dibandingkan beton tanpa bakar. Hal ini disebabkan karena terjadi perbedaan angka muai antara agregat dan pasta semen. Jika suhu dinaikkan hingga $800^{\circ} \mathrm{C}$, maka pasta semen akan menyusut dan agregat mengembang sehingga akan terdapat poripori yang lebih besar terutama pada agregat kasar. Selain itu juga terdapat retakan yang terjadi akibat tekanan uap air atau gas yang terperangkap pada beton yang tidak mudah mengalir melalui pori-pori ke daerah yang lebih dingin. Retakan pada beton tersebut juga memperbesar ruang pori pada beton sehingga mempengaruhi besarnya persentase porositas. Berdasarkan uraian di atas maka penelitian ini mencoba meneliti hubungan peningkatan porositas dengan kuat tekan dan kuat tarik belah beton pasca bakar. Selain itu juga akan diteliti hubungan kedalaman penetrasi panas terhadap persentase porositas beton pasca bakar.

Hasil penelitian menunjukkan bahwa peningkatan porositas beton sebanding dengan volume beton yang mengalami penetrasi panas dengan temperatur 400 $800^{\circ} \mathrm{C}$. Hal lain juga menunjukkan bahwa porositas beton yang meningkat sebesar 20,695\% tersebut menyebabkan kuat tekan turun sebesar 53,665 \% dan kuat tarik belah turun sebesar 49,641\%.

c. Abdul Rochman ( Jurusan Teknik Sipil -Universitas Muhammadiyah Surakarta) Pada struktur beton yang mengalami kebakaran, kekuatan beton akan dipengaruhi oleh perubahan temperatur, tingkat dan lama pemanasan, jenis dan perilaku pembebanan, jenis dan ukuran agregat, dan faktor air-semen. 
Pengaruh pemanasan sampai pada temperature $\quad 200^{\circ} \mathrm{C}$ sebenarnya menguntungkan terhadap beton, karena akan menyebabkan penguapan air (dehidrasi) dan penetrasi ke dalam rongga-rongga beton lebih dalam, sehingga memperbaiki sifat lekatan antar partikel-partikel C-S-H. Penelitian Wijaya, (1999, dalam Priyosulistyo, 2000) menunjukkan bahwa kuat-tekan beton benda uji silinder maupun kuat lentur benda uji yang dipanaskan dalam tungku pada temperature $200^{\circ} \mathrm{C}$ meningkat sekitar 10-15\% dibandingkan dengan beton normal yang tanpa dipanaskan. Warna beton yang dipanaskan pada temperatur ini umumnya berwarna hitam gelap. Selanjutnya jika panas dinaikkan lagi, kekuatan beton cenderung menurun. Pada suhu antara $400-600^{\circ} \mathrm{C}$, penurunan kuat-tekan dan kuat lentur hingga mencapai $50 \%$ dari kuat tekan sebelumnya. Penurunan ini disebabkan karena terjadinya proses dekomposisi unsur C-S-H yang terurai menjadi kapur bebas $\mathrm{CaO}$ serta $\mathrm{SiO} 2$ yang tidak memiliki kekuatan sama sekali. Karena unsure $\mathrm{C}-\mathrm{S}-\mathrm{H}$ merupakan unsur utama yang menopang kekuatan beton, maka pengurangan C-S-H yang jumlahnya cukup banyak akan sangat mengurangi kekuatan beton. Jika suhu dinaikkan sampai mencapai $1000^{\circ} \mathrm{C}$ terjadilah proses karbonisasi yaitu terbentuknya Calsium Carbonat (CaCo3) yang berwarna keputih-putihan sehingga merubah warna permukaan beton menjadi lebih terang (pink keputihputihan). Disamping itu pada temperatur ini terjadi penurunan lekatan antara batuan dan pasta semen, yang ditandai oleh retak-retak dan oleh kerapuhan beton (mudah dipecah dengan tangan). Kerusakan beton dapat pula disebabkan oleh perbedaan angka muai antara agregat dan pasta semen. Perbedaan ini menyebabkan kerusakan pada interfacial zone sehingga lekatan antar batuan menjadi berkurang banyak.
Pada temperatur kamar angka muai batuan pada umumnya lebih rendah dari pada pasta-semen. Sampai pada temperature $\quad 200^{\circ} \mathrm{C}$ pasta-semen menyusut sedang batuan mengembang. Perbedaan ini dapat menimbulkan retakretak pada beton. Namun yang paling nyata kerusakan beton mengelupas disebabkan oleh tekanan uap air (5 - 7,5 volume) atau gas yang terperangkap di dalam beton. Semakin rapat beton, maka semakin mudah terjadi pengelupasan oleh panas, karena uap air tidak mudah mengalir melalui pori ke dalam daerah yang lebih dingin. Jika terjadi peningkatan suhu yang cepat diikuti oleh hambatan aliran uap air ke sebelah dalam dan jika tersumbat akibat rapatnya beton, maka berpotensi menimbulkan ledakan, terlebih lagi pada beton mutu tinggi.

Dari beberapa hasil penelitian terdahulu terlihat adanya pengaruh kekuatan beton (struktur beton) pasca kebakaran, dalam penelitian ini penulis mencoba menganalisa pengaruh struktur beton keseluruhannya terhadap kelayakan dari bangunan tersebut, apakah bangunan setelah pasca kebakaran masih layak atau tidak.

Sesuai dengan latar belakang dan permasalahan yang dihadapi maka tujuan dari hasil penelitian ini untuk mendapatkan hasil sebagai berikut :

a. Hasil pemeriksaan visual gedung pasar koppas pasca kebakaran.

b. Hasil pengujian bahan, gedung pasar koppas pasca kebakaran.

c. Hasil pemodelan, disain dan cek kapasitas struktur gedung pasar koppas pasca kebakaran.

d. Hasil utilitas bangunan pasar koppas pasca kebakaran

e. Upaya - upaya yang dilakukan dalam rangka terpenuhi kelayakan struktur gedung pasar koppas pasca kebakaran serta rekomendasi yang diberikan ke Pemerintah Kota Padang. 


\section{METODOLOGI}

Metodologi yang digunakan dalam pelaksanaan pemeriksaan struktur bangunan bersifat menyeluruh (comprehensive), yaitu dengan metode kualitatif dan kuantitatif. Metode kualitatif yaitu dengan melakukan pengamatan dan pemeriksaan lapangan secara visual. Pengukuran kualitatif dilakukan dengan melakukan pencatatan/ inventarisasi kondisi bangunan dan kerusakan-kerusakan yang ada pada bangunan eksisting, penelusuran terhadap data-data bangunan, pengambilan foto, dan pemeriksaan visual untuk melihat kondisi komponen struktur yang ada (existing). Di sisi lain, pemeriksaan juga dilakukan dengan metode kuantitatif, yaitu melakukan serangkaian pengujian pada struktur bangunan serta pengukuran konfigurasi bangunan, dan dimensi komponen struktur.

Data-data yang diperoleh dari bangunan tersebut, kemudian dijadikan dasar penentuan mutu bahan yang ada (mutu beton serta jumlah dan diameter tulangan). Selanjutnya dilakukan perhitungan ulang struktur, dan evaluasi bangunan yang ada secara keseluruhan.

Selengkapnya, kegiatan pemeriksaan bangunan dapat disusun dalam beberapa langkah- langkah kegiatan. Adapun urutan langkah-langkah tersebut adalah sebagai berikut:

a. Penelusuran data bangunan

Pekerjaan penelusuran data bangunan meliputi penelusuran informasi mengenai dibangunnya gedung.

b. Pemeriksaan visual bangunan

Pemeriksaan visual bangunan meliputi pemeriksaan sistem struktural dan komponen non struktural, serta konfigurasi geometri dari komponen struktur tersebut.

c. Pengukuran bangunan
Pengukuran bangunan dilakukan unrtuk mengetahui konfigurasi bangunan. Hal ini juga dapat berfungsi sebagai alat konfirmasi kondisi geometrik bangunan eksisting.

d. Pemeriksaan kerusakan yang terjadi

Pemeriksaan dilakukan terhadap kerusakan yang terjadi pada komponen struktur maupun non struktur dengan melakukan pengamatan secara visual.

e. Pengujian lapangan dan laboratorium Pengujian lapangan dilakukan untuk mendapatkan data mutu bahan struktur gedung, dengan metode non-destruxctive dan destructive. Kegiatan ini berupa: uji mutu beton permukaan dengan alat palu beton, pengukuran homogenitas beton, pengukuran diameter dan jarak tulangan, pengambilan beton inti dengan alat cored drill, pengamatan kelelahan tulangan. Sedangkan di laboratorium dilakukan uji kuat tekan beton inti. Uji tarik tulangan

f. Pengambilan foto

Pengambilan foto terhadap kondisi bangunan, komponen struktur dan komponen non struktur untuk diamati penyebab dari kerusakan yang terjadi, serta sebagai alat untuk mengukur tingkat kerusakan bangunan, pengambilan foto juga berfungsi sebagai dokumentasi.

g. Evaluasi data dan analisa struktur bangunan

Evaluasi data bangunan ditujukan untuk mengevaluasi secara keseluruhan kondisi bangunan eksisting, berdasarkan seluruh data yang meliputi: informasi umum gedung, jenis kerusakan pada komponen struktur dan non struktur, serta kelayakan dari komponen tersebut.

\section{Bagan Alir}

Tahap pelaksanaan pemeriksaan kelayakan bangunan secara keseluruhan dapat disampaikan bagan alir berikut ini: 


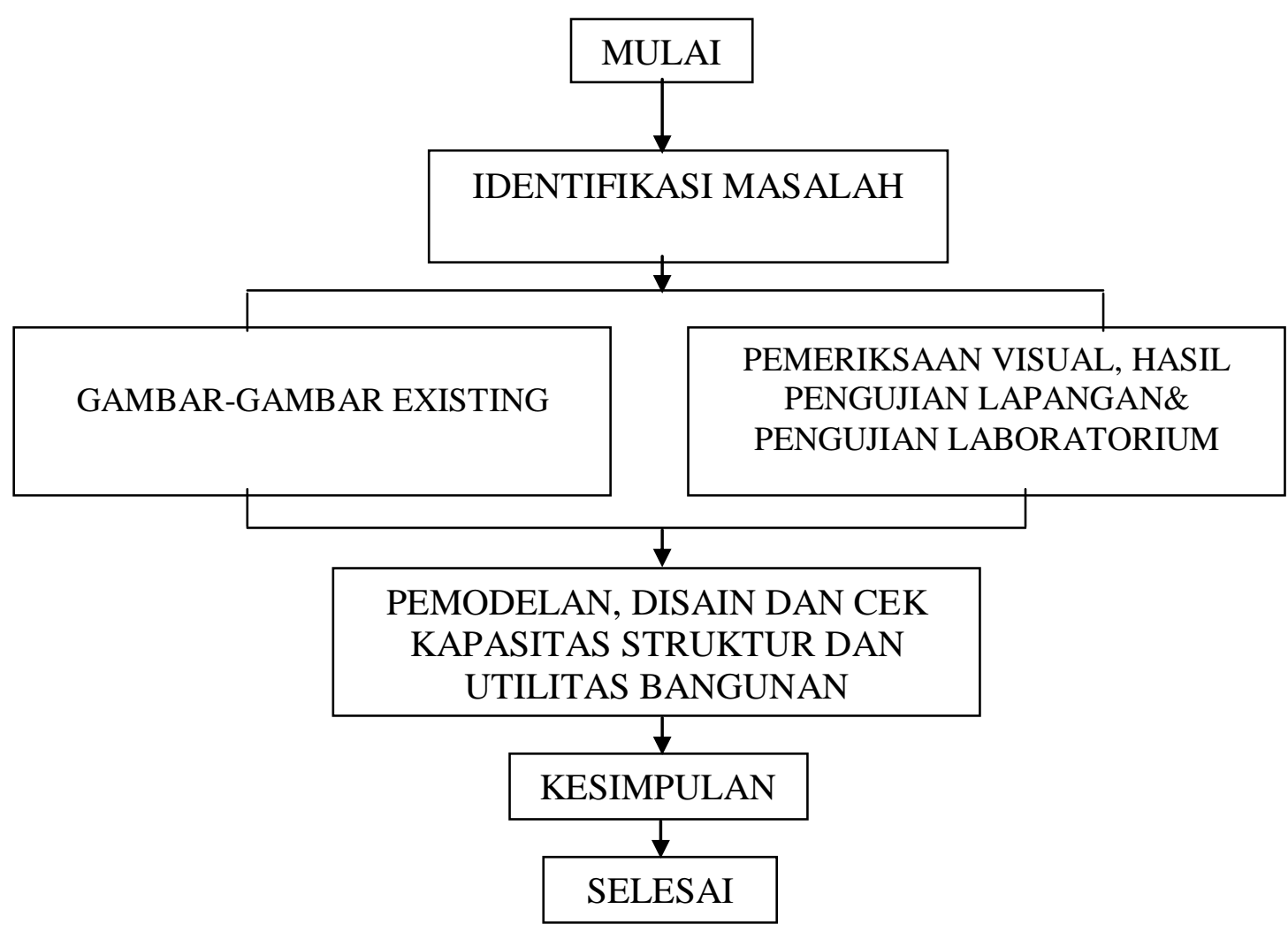

Gambar 1. Bagan Alir

HASIL

\section{Hasil Pemeriksaan Visual \\ a. Data Bangunan}

Pasar Koppas Padang

Data bangunan adalah sebagai berikut:

Nama bangunan : Pasar Koppas Padang

Jumlah tingkat : 3 (tiga) tingkat

Sistem struktur : Konstruksi rangka beton bertulang dengan konstruksi atap dari plat beton (plat dak).

\section{Lantai I :}

Kolom-kolom berbentuk persegi berukuran $80 / 80$ dan 60/60 cm. Secara umum kondisi kolom masih baik, hanya $5 \%$ kolom yang mengalami keretakan pada bagian joint pertemuan kolom dan balok. Keretakan tipikal ini terjadi sebagian besar di pertemuan kolom dengan balok pada bagian luar (joint eksterior).

Balok berukuran 40/80 dan 30/70, terlihat beberapa bentang terkelupasnya selimut beton, beton telah mengalami perkapuran akibat suhu kebakaran dan tulangan telah meleleh ( 3 bentang balok). Ada beberapa panel lantai telah bocor dan selimut beton telah mengelupas.

\section{Lantai II \& III:}

Kolom-kolom berbentuk persegi berukuran 80/80 dan 60/60 cm, balok berukuran 40/80 dan 30/70. Secara umum kondisi kolom dan balok masih baik.

\section{b. Konfigurasi bangunan}

Berdasarkan survey lapangan untuk konfigurasi bangunan untuk mendapatkan denah bangunan. Denah ini terdiri dari denah balok, kolom dan pelat. Denah ini merupakan acuan dalam pembuatan model bangunan pada saat analisa struktur selanjutnya. Masing lantai luas bangunan adalah 68 x $48 \mathrm{~m}$, dan detail gambar denah dapat dlihat pada lampiran gambar 


\section{Hasil Pengujian Lapangan}

Pengujian lapangan berupa identifikasi tulangan terpasang, pengukuran leveler dan pengujian mutu beton kondisi eksisting pasca kebakaran. Berikut disampaikan hasil pengujian di lapangan tersebut.

\section{a. Pengukuran Leveler}

Pengukuran leveler balok bertujuan untuk memeriksa apakah terjadi lendutan pasca kebakaran.

Pengukuran dilakukan pada plat lantai I, dengan hasil sebagai berikut;

Tabel 2. Hasil Pengukuran Penurunan

\begin{tabular}{llll}
\hline No. & Lokasi & \multicolumn{1}{c}{ Data/Beda Tinggi } & \multicolumn{1}{c}{ Hasil } \\
\hline & & Elevasi ujung kiri $=2.80 \mathrm{~m}$ & Diprediksi telah terjadi \\
1. & Balok I J - 6 & Elevasi ujung kiri $=2.80 \mathrm{~m}$ & lendutan balok $=4 \mathrm{~cm}$ \\
& Plat Lantai I & Elevasi tengah $=2.76 \mathrm{~m}$ & \\
\hline & & Elevasi ujung kiri $=2.78 \mathrm{~m}$ & Diprediksi telah terjadi \\
2. & Balok I 6 - 7 & Elevasi ujung kiri $=2.78 \mathrm{~m}$ & lendutan balok $=2 \mathrm{~cm}$ \\
& Plat Lantai I & Elevasi tengah $=2.76 \mathrm{~m}$ & \\
\hline
\end{tabular}

\section{b. Identifikasi Tulangan Terpasang} Identifikasi Tulangan dilakukan pada beberapa kolom, balok, dan pelat lantai sebagai sample untuk mewakili, disetiap lantai bangunan. Dalam pemeriksaan berpedoman pada gambar rencana (design drawing) yang dibuat oleh PT. Bipatrada, dan juga dilakukan identifikasi tulangan terpasang yang dilakukan dengan menggunakan alat Wallscanner D-Tect 100 Bosch dan pembobokan beton (Chipping concrete) serta pengamatan selimut beton yang terbuka. Pengambilan data dilakukan dengan teknik sampling sehingga dapat dilakukan rekonstruksi detail penulangan struktur beton bertulang yang terpasang.

\section{c. Hasil Uji Bahan}

Uji kualitas bahan yang dilakukan pada gedung Pasar Koppas Padang, pengujian palu beton (Hammer schemids test), pengambilan sampel beton inti (core drill). Pengujian palu beton dilakukan pada komponen kolom, dan balok, untuk mengetahui mutu atau kualitas beton permukaan pada komponen yang diuji, pemilihan titik dilakukan di lapangan diasumsikan dapat mewakili mutu atau kualitas bahan beton komponen struktur. Jumlah titik uji yang telah dilakukan adalah

- Kolom Lantai I 384 titik.

- Kolom Lantai II 368 titik

- Kolom Lantai III 368 titik

- Balok Lantai I 336 titik.

- Balok Lantai II 328 titik

- Balok Lantai III 318 titik

Rekapitulasi hasil uji dapat diamati melalui table-tabel berikut: 
Tabel 2. Hasil Pengukuran Mutu Beton (Uji Palu Beton)

\begin{tabular}{|c|c|c|c|c|}
\hline \multirow[t]{2}{*}{ No. } & \multirow{2}{*}{\multicolumn{2}{|c|}{ Posisi Struktur }} & \multicolumn{2}{|c|}{$\begin{array}{c}\text { Kuat Tekan Beton } \\
\text { Rata-rata }\end{array}$} \\
\hline & & & $(\mathrm{MPa})$ & $(\mathrm{Kg} / \mathrm{cm} 2)$ \\
\hline 1 & Kolom : & & & \\
\hline 1.1 & Kolom Lantai I & ( 384 titik) & 19.81 & 194.33 \\
\hline 1.2 & Kolom Lantai II & ( 368 titik) & 19.83 & 194.53 \\
\hline \multirow[t]{2}{*}{1.3} & Kolom Lantai III & ( 368 titik) & 19.82 & 194.44 \\
\hline & \multicolumn{2}{|c|}{ Rata-rata mutu beton Kolom } & 19.82 & 194.43 \\
\hline 2 & Balok : & & & \\
\hline 2.1 & Balok Lantai II & ( 336 titik) & 19.55 & 191.78 \\
\hline 2.2 & Balok Lantai III & ( 328 titik) & 19.49 & 191.18 \\
\hline \multirow[t]{3}{*}{2.3} & Balok Lantai IV & (318 titik) & 19.50 & 191.26 \\
\hline & \multicolumn{2}{|c|}{ Rata-rata mutu beton Balok } & 19.51 & 191.40 \\
\hline & \multicolumn{2}{|c|}{$\begin{array}{c}\text { Rata-rata mutu beton Kolom \& } \\
\text { Balok }\end{array}$} & 19.67 & 192.92 \\
\hline
\end{tabular}

\section{Hasil Pengujian Laboratorium Uji Kuat Tekan Beton Inti}

Pengujian kuat tekan (compressive strength) dilakukan laboratorium terhadap benda uji berbentuk silinder yang diamati di lapangan. Uji kuat tekan beton inti (core drill) dilakukan dengan hasil rata-rata $=$ $193.87 \mathrm{~kg} / \mathrm{cm}^{2}$

\section{PEMBAHASAN}

\section{Analisis Struktur dan Cek Kapasitas}

Analisis struktur dan chek Kapsitas struktur KOPPAS dilakukan dengan bantuan program komputer berbasiskan Metode Elemen Hingga,. Analisis struktur dan perencanaan komponen struktur dilakukan secara terintegrasi. Untuk maksud tersebut telah dibuat model struktur mewakili struktur yang sesungguhnya. Selanjutnya model ini akan dianalisis dan direncanakan untuk selanjutnya diterapkan pada struktur bangunan yang sesungguhnya. Dengan bantuan program komputer ini akan dapat diinvestigasi perilaku struktur bangunan akibat berbagai beban yang diberikan. Dengan demikian akan diperoleh suatu bentuk dan pola struktur yang betul-betul handal untuk daerah tertentu.

\section{Pemodelan dan Data Teknis Struktur}

Analisis dan perencanaan struktur dilakukan dengan asumsi-asumsi berikut. Asumsi-asumsi tersebut digunakan untuk mempermudah pemodelan struktur.

1. Komponen balok dan kolom bertemu pada garis sumbu utamanya masing-masing.

2. Pelat lantai dapat diasumsikan sebagai diafragma lantai kaku tak terhingga pada bidangnya.

3. Efek rigid end zone pada komponen struktur balok diabaikan.

4. Besar dan arah beban statik konstan.

5. Untuk balok dan kolom digunakan Hermitian Frame Element.

6. Material bersifat Isotropik dan linear elastik.

7. Deformasi kecil sehingga dapa dilakukan analisis linear.

8. Struktur stabil geometrik.

9. Metode perakitan menggunakan metode kekakuan langsung. 
10. Kondensasi dilakukan pada 3

DOF/lantai untuk beban lateral.

Analisis dan perencanaan struktur dilakukan dengan pemodelan 3-dimensi seperti diperlihatkan dalam Gambar 4.1 Spesifikasi teknis struktur ditentukan adalah sebagai berikut,

Dimensi struktur

Mutu beton

Mutu baja

Fungsi bangunan

Ketahanan terhadap gempa

Analisis beton bertulang
: $\quad$ Sesuai dengan data Eksisting

: Disesuaikan dari hasil forensik engineering

: Disesuaikan dari hasil forensik engineering

: $\quad$ Toko dan Parkir

: Wil. 5 (tanah sedang) SNI 03-1726-2002

: $\quad$ SNI T-15-1991-03

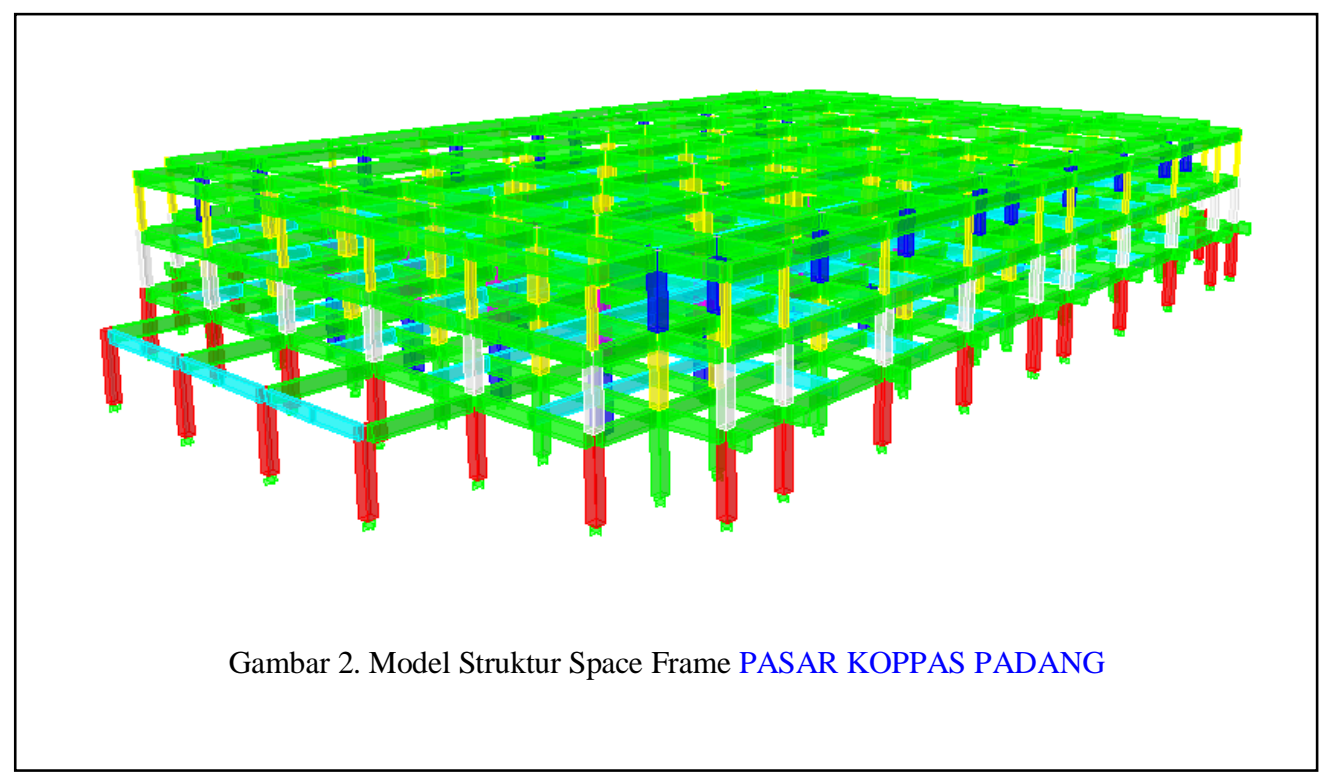

Penentuan wilayah gempa mengacu kepada SNI 03-1726-2002 seperti diperlihatkan dalam Gambar 3. 


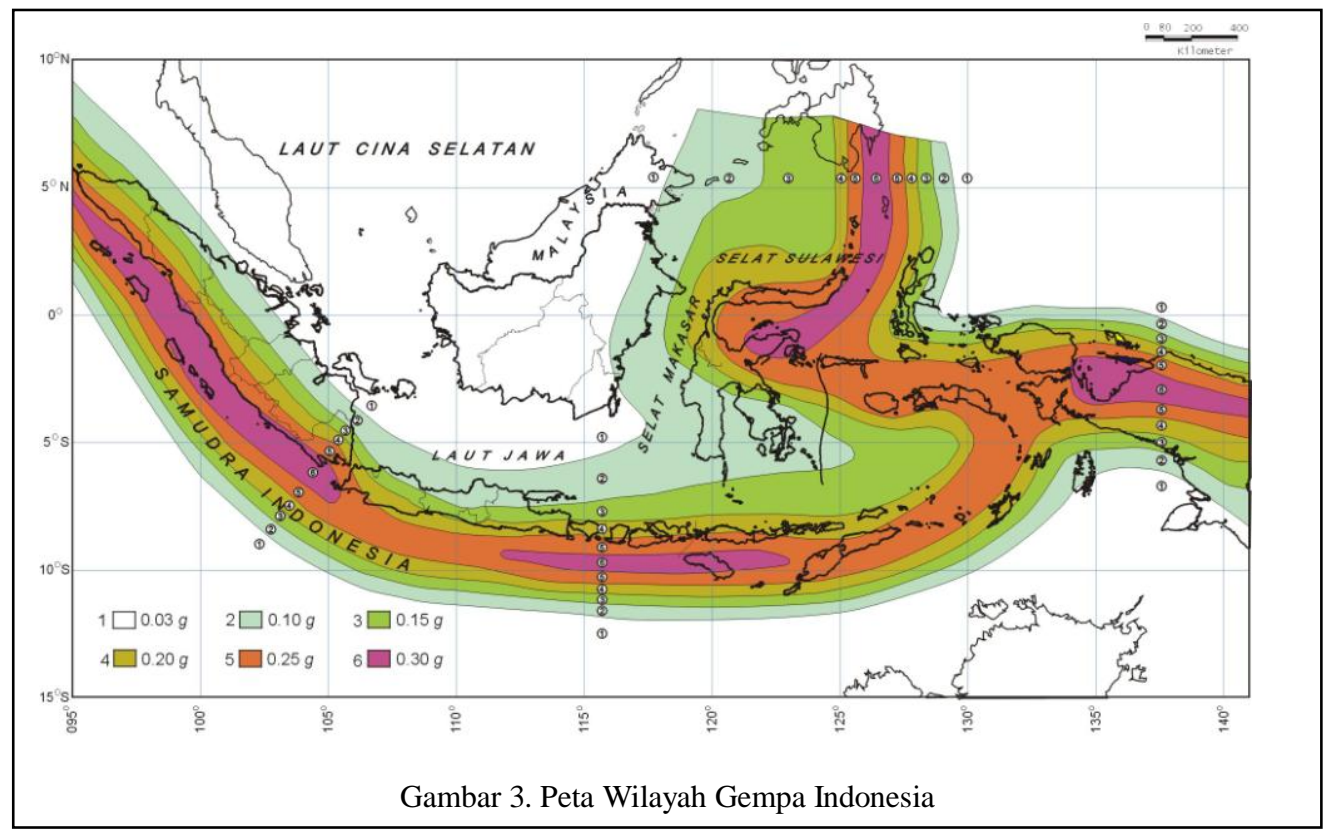

\section{a. Sumary Kapasitas Kolom Dan Balok}

1. Hampir seluruh dari hasil pengambilan data kekuatan material beton dan baja tulangan serta data geometris / dimensi elemen struktur Analisis Kapasitas kolom, dan di komparasi dengan hasil perhitungan kapasitas pasca Kebakaran dapat disimpulkan struktur kolom dan balok masih kuat, kokoh dan stabil.

2. Unit Balok yang mengalami penurunan kapasitas diakibatkan berkurangnya mutu beton akibat kebakaran perlu dilakukan repair atau retrofiting untuk menghindari kegagalan struktur.

3. Secara Global Kekuatan, kekakuan dan kestabilan Struktur Bangunan Gedung KOPAS Masih Dalam tingkat keamanan yang cukup.

\section{b. Hasil Forensik Struktur Beton Bertulang}

Setelah melakukan investigasi dan penelitian di lapangan pada bangunan Pasar Koppas Padang pasca kebakaran, maka bangunan yang mengalami dampak yang paling parah adalah sebagai berikut :

a. Beton balok yang telah mengalami kerusakan berat yaitu;

- Balok I J - 6

- Balok M 5-6

- Balok I 5-6
- Balok I J - 6

- Balok I 6 - 7

- Balok I J - 5

b. Balok yang telah mengalami lendutan $(2-4 \mathrm{~cm})$ yaitu;

- Balok I J - 6

- Balok I 6 - 7

c. Plat lantai yang telah mengalami kerusakan berat yaitu;

- Panel plat lantai I5 - J5 - I6 - J6

- Panel plat lantai K5 - L5 - K6 - L6

- Panel plat lantai I4' - J4' - I5 $-\mathrm{J} 5$

- Panel plat lantai H5 - I5 - H6 - I6

d. Join Kolom yang mengalami rusak sedang

- Join Kolom atas “ I 5 ”

- Join Kolom atas "J 6 "

- Join Kolom atas "I 6 "

- Join Kolom atas "J 6 ”

Struktur lainnya pada lantai dasar, lantai I, lantai II dan Lantai III masih dalam kondisi layak struktur. 


\section{Utilitas Bangunan}

Analisis Perhitungan Air Bersih dan Pemadam Kebakaran

\section{a. Air Bersih}

Dasar Perhitungan :

Pasar ditentukan 3 Itr/hari/orang

Kios/Toko 100 liter/hari/kios/los

Kantor Pengelola 10 Itr/hari/orang

(Referensi perhitungan Perencanaan dan pemeliharaan sistem Plambing Soufyan Moh.Noerbambang-Takeo Morimura)

\section{Lantai Dasar :}

Perhitungan :

$$
\begin{aligned}
& \text { - Kios/Toko } \\
& =84 \times 100 \text { liter } \\
& =8.400 \text { liter/hari } \\
& \text { - Pasar } \quad \text { diasumsi } 4 \mathrm{~m} 2 / \text { orang } \\
& =3.264 \mathrm{~m} 2, \text { dimana penghuni } \\
& =3.264 \mathrm{~m} 2 / 4 \\
& =816 \mathrm{orang} \times 3 \text { liter/orang } \\
& =2.448 \text { liter/hari }
\end{aligned}
$$

\section{Lantai I :}

Perhitungan :

- Kios/Toko

$=84 \times 100$ liter

$=8.400$ liter $/$ hari

- Pasar

$=2.749 \mathrm{~m} 2$, dimana penghuni diasumsi 4 m2/orang

$=3.264 \mathrm{~m} 2 / 4$

$=687$ orang $\mathrm{x} 3$ liter/orang

$=2.061$ liter $/$ hari

- Kantor pengelola $=515 \mathrm{~m} 2$, dimana penghuni diasumsi $8 \mathrm{~m} 2 / 1$ orang $=515 \mathrm{~m} 2 / 8 \times 100$ liter/orang $=6.440$ liter $/$ hari

Total keseluruhan Lt.Dasar \& I

$$
\begin{aligned}
& =2.448+6.440 \\
& =8.888 \text { liter } / \text { hari }
\end{aligned}
$$

\section{Lantai II \& III}

$$
\begin{array}{ll}
\text { - Fungsi } & =\text { area parker } \\
\text { - Kapasitas } & =160 \text { kendaraan }
\end{array}
$$

- Kebutuhan air = 20 1/kendaraan

- Kebutuhan air

$$
\begin{aligned}
& =2 \times 160 \times 20 \\
& =6.4001 / \text { hari }
\end{aligned}
$$

Total kebutuhan Lt. Dasar, I, II \& III :

$$
\begin{aligned}
& =8.888+6.400 \\
& =13.2881 / \text { hari } \\
& =13.3 \mathrm{M}^{3} / \text { hari }
\end{aligned}
$$

Kebutuhan air bersih untuk siram taman dan mengatasi kebocoran diperkirakan $5 \%$

Total keseluruhan kebutuhan air bersih bangunan pasar Koppas

$$
\begin{aligned}
& =105 \% \times 13.3 \mathrm{~m} 3 \\
& =13,97 \mathrm{~m} 3 / \text { hari }
\end{aligned}
$$

\section{b. Kapasitas Pompa Utama Pemadam Kebakaran}

Sesuai SNI 03-1745-2000 pasal 7.9.1.3.2 maka kapasitas pompa dihitung sebagai berikut:

Hydrant

$$
\begin{aligned}
& =\text { Riser } 1+\text { Riser } 2 \\
& =500 \text { USGPM }+250 \text { USGPM } \\
& =750 \text { USGPM }
\end{aligned}
$$

\section{c. Air Pemadam Kebakaran}

Pompa pemadam

$$
\begin{aligned}
& =750 \text { USGPM } \\
& =2.838 \text { liter } / \text { menit }
\end{aligned}
$$

Kebutuhan air pemadam kebakaran diperhitungkan untuk 30 menit

$$
\begin{aligned}
& =2.838 \text { liter } \times 30 \text { menit } \\
& =85.140 \text { liter } \\
& =85 \mathrm{~m} 3
\end{aligned}
$$

\section{d. Kapasitas Air yang dibutuhkan selama 1 hari, adalah :}

$$
\begin{aligned}
& \text { Air bersih } \\
& \quad=13,97 \mathrm{~m} 3
\end{aligned}
$$

Air pemadam kebakaran

$$
=85 \mathrm{~m} 3
$$

Total $=98.97 \mathrm{~m} 3$

\section{SIMPULAN}

Hasil analisis dan evaluasi kegiatan pemeriksaan/pengujian kehandalan struktur 
gedung Pasar Koppas Padang, maka dapat diambil kesimpulan sebagai berikut:

\section{Hasil pemeriksaan Visual}

Hasil pemeriksaan visual di lapangan investigasi dan penelitian di lapangan pada bangunan Pasar Koppas Padang struktur yang mengalami kerusakan akibat kebakaran, hanya sebagian stuktur pada Lantai Dasar, dengan dapat dirangkum sebagai berikut:

\section{Lantai Dasar}

a. Beton balok yang telah mengalami kerusakan berat yaitu;

- Balok I J - 6

- Balok M 5-6

- Balok I 5 -6

- Balok I J - 6

- Balok I 6-7

- Balok I J - 5

b. Balok yang telah mengalami lendutan (2 $-4 \mathrm{~cm}$ ) yaitu;

- Balok I J - 6

- Balok I 6-7

c. Plat lantai yang telah mengalami kerusakan berat yaitu;

- Panel plat lantai I5 - J5 - I6 - J6

- Panel plat lantai K5 - L5 - K6 - L6

- Panel plat lantai I4' - J4' - I5 - J5

- Panel plat lantai H5 - I5 - H6 - I6

d. Join Kolom yang mengalami rusak sedang

- Join Kolom atas " I 5 "

- Join Kolom atas " J 6 ",

- Join Kolom atas "I 6"

- Join Kolom atas "J 6 "

Struktur lainnya pada lantai dasar, lantai I, lantai II dan Lantai III masih dalam kondisi layak struktur.

\section{Hasil Uji Bahan}

a. Hammer Test

$\begin{array}{ll}\text { - Kolom } & : 1.120 \text { titik } \\ & : 194,43 \mathrm{Kg} / \mathrm{cm}^{2} \\ & (\text { Rerata) } \\ & : 982 \text { titik } \\ \text { - Balok } & : 191,40 \mathrm{Kg} / \mathrm{cm}^{2} \\ & \text { (Rerata) }\end{array}$

b. Hasil Pengujian Laboratorium Uji Kuat Tekan Beton Inti

Pengujian kuat tekan (compressive strength) dilakukan laboratorium terhadap benda uji berbentuk silinder yang diamati di lapangan. Uji kuat tekan beton inti (core drill) dilakukan dengan hasil rata-rata $=193.87 \mathrm{~kg} / \mathrm{cm}^{2}$

c. Tingkat Keseragaman Beton

Pengujian tingkat keseragaman beton menunjukkan keseragaman beton pada gedung Pasar Koppas Padang adalah kurang baik.

d. Kuat Tarik Baja

Baja tulangan yang digunakan pada struktur bangunan gedung Pasar Koppas hanya baja ulir kuat tarik (fy) 3.221 $\mathrm{kg} / \mathrm{cm}^{2}$.

\section{Pemodelan, Disain dan Cek Kapasitas Struktur}

Berdasarkan data lapangan, laboratorium, bangunan berfungsi sebagai pasar dan kondisi eksisting ada, dilakukan Permodelan, Disain dan Chek Kapasitas Struktur dengan software, maka didapat hasil sebagai berikut;

a. Hampir seluruh dari hasil pengambilan data kekuatan material beton dan baja tulangan serta data geometris / dimensi elemen struktur Analisis Kapasitas kolom, dan di komparasi dengan hasil perhitungan kapasitas pasca Kebakaran dapat disimpulkan struktur kolom dan balok masih kuat, kokoh dan stabil.

b. 2 Unit Balok yang mengalami penurunan kapasitas diakibatkan berkurangnya mutu beton akibat kebakaran perlu dilakukan repair atau retrofiting untuk menghindari kegagalan struktur.

c. Secara global kekuatan, kekakuan dan kestabilan Struktur Bangunan Gedung Koppas masih dalam tingkat keamanan yang cukup.

\section{Utilitas Bangunan}

a. Air bersih.

Daya layan air bersih masih kurang baru memenuhi 56,3 \% dari kebutuhan normal, untuk itu perlu dilakukan 
perbaikan instalasi air bersih untuk memberikan pelayanan optimal.

b. Instalasi Listrik.

Perlu dilakukan perbaikan instalasi pasca kebakaran, dan perlu diberi alarm konsleting masing-masing blok took.

c. Hydran Kebakaran

Perlu dilakukan perencanaan dan pelaksanaan yang baik terhadap terhadap kesiapan Hydran kebakaran, karena merupakan pesyaratan mutlak pada bangunan publik seperti pasar Koppas.

\section{SARAN}

a. Perlu dilakukan repair atau retrofit dengan cara dan metoda yang tepat oleh Pemerintah Kota Padang / Dinas yang terkait.

b. Perbaikan yang dilakukan pedagang umumnya lebih bersifat mengembalikan bentuk arsitekturnya saja, belum ke perbaikan komponen struktur (plat lantai, balok kolom) yang terbakar.

c. Perlunya Pengamanan konsleting listrik dan alarm.

d. Hydran kebakaran perlu di redisain kembali.

\section{DAFTAR PUSTAKA}

Abdul Rochman, Estimasi Kekuatan Sisa dan Teknologi Perbaikannya, dinamika TEKNIK SIPIL, Volume 6, Nomor 2, Juli 2006 : $94-100$.

Elvi Roza Syofyan,Yurisman, Mukhlis , Tinjauan Kelayakan Struktur Pasar Inpres IV Kodya Padang Pasca Gempa Jurnal Poli Rekayasa vol. VIII No. 1 Oktober 2012 : 71 - 82.

Irma Aswani Ahmad, Nur Anny Suryaningsih Taufieq, Abdul Hamid Aras, Analisis Pengaruh Temperatur terhadap Kuat Tekan Beton, Jurnal Teknik Sipil Vol. 16 No. 2 Agustus 2009: 63.

$$
\begin{gathered}
\text { Pedoman Perencanaan } \\
\text { untuk Rumah dan } \\
\text { KBI }-1.3 .53 .1987 .
\end{gathered}
$$

SNI-03-4430-1997 tentang Metode Pengujian Kuat Tekan Elemen Struktur Beton Dengan Alat Palu Beton

SNI 03-2492-1991 tentang Metode Pengambilan Benda Uji Beton Inti Di Lapangan

SNI 03-3403-1994 tentang metode pengujian kuat tekan beton inti pemboran di laboratorium

SNI 03-4802-1998, Kriterian Keseragaman/Homogenitas Kualitas Beton

SNI 03-2847-2002 tentang Tata Cara Perhitungan Struktur Beton Untuk Bangunan Gedung.

SNI 03-1726-2002 tentang Tata Cara Perencanaan Ketahanan Kebakaran Untuk Bangunan Gedung.

SNI 03-1729-2002 tentang Tata Cara Perencanaan Struktur Baja Untuk Bangunan Gedung.

Yurisman \& Elvi Roza Syofyan, Kajian Kelayakan Struktur Bangunan Pasca Gempa (Studi Kasus Gedung Pasar Inpres II Kota Padang) Jurnal Ilmiah REKAYASA SIPIL vol. VIII No. 1 April $2012: 48-55$ 